International scientific and technical conference

DOI: $10.34185 / 1991-7848 . i t m m .2020 .01 .020$

\title{
ПРИНЦИПИ ПОБУДОВИ МАТЕМАТИЧНОЇ МОДЕЛІ СИСТЕМИ ДИСПЕТЧЕРИЗАЦІї ВУГІЛЬНИХ ШАХТ
}

\author{
Малієнко А. В., канд. техн. наук \\ доцент кафедри системного аналізу і управління
}

Національний технічний університет «Дніпровська політехніка», Дніпро, Україна.

КЛючові слова: МАТЕМАТИЧНА МОДЕЛЬ, СИСТЕМ ОПЕРАТИВНО-

ДИСПЕТЧЕРСЬКОГО УПРАВЛІННЯ, ПРИЙНЯТТЯ РІШЕНЬ, ЕФЕКТИВНЕ УПРАВЛІННЯ.

Вступ. Для стабілізації обсягів видобутку, згладжування нерівномірності видобутку, транспортування, а головне зменшення простоїв обладнання технологічних комплексів гірничого підприємства необхідно впровадження та модернізація існуючих систем диспетчерського управління на основі вдосконалення математичних моделей СодУ (систем оперативнодиспетчерського управління) [1].

Мета. Розробка методу побудови ММ (математичної моделі) СОДУ, яка в свою чергу дозволить скоротити час і підвищити ефективність прийняття рішень диспетчером вугільних шахт.

Основний матеріал. При побудові ММ СОДУ вугільної шахти, розгляд шахти відбувається 3 точки зору складної ТС (технологічної системи), при формуванні оптимального поєднання взаємопов'язаних підсистем, що складаються 3 технологічних елементів, кожен 3 яких характеризується якісними та кількісними характеристиками.

Основою формування цих підсистем є:

- функціональна і технологічна однорідність технологічних процесів;

- чітко виражена ієрархія внутрішнього побудови гірничого підприємства;

- внутрішня логічний взаємозв'язок i багатоваріантність розвитку ситуацій при управлінні технологічним процесом.

Ефективне функціонування вугільної шахти, досягається шляхом ефективного управління СОДУ при оптимальному поєднанні параметрів, елементів, використанням MM, методу прийняття рішення на основі дослідження прийнятої цільової функції, ï обмежень, які формуються в 
залежності від розв'язуваної задачі на певному етапі роботи гірничого підприємства.

Безліч розрахункових варіантів ефективного управління ведення гірських робіт на шахті - це поєднання числа варіантів управління, що представляють собою можливі сумісні комбінації, технологічні схеми підземних гірських робіт (процесів), підсистеми кількісних та якісних параметрів технологічних процесів: очисних робіт $\left(Y_{1}\right)$, гірничопідготовчих робіт $\left(Y_{2}\right)$, підтримки гірських виробіток $\left(Y_{3}\right)$, монтажу-демонтажу обладнання $\left(Y_{4}\right)$, дегазації і запобігання викидів $\left(Y_{5}\right)$, способу управління крівлею $\left(Y_{6}\right)$, підземного транспорту $\left(Y_{7}\right)$, вентиляції $\left(Y_{8}\right)$, підйому $\left(Y_{9}\right)$, технологічний комплекс поверхні $\left(Y_{10}\right)$. Таким чином умовами оптимального рішення для підприємства гірничої галузі є досягнення оптимального значення функції мети.

$$
F=\left\{Y_{1}, Y_{2}, Y_{3}, Y_{4}, Y_{5}, Y_{6}, Y_{7}, Y_{8}, Y_{9}, Y_{10}\right\} .
$$

Мінімальні і максимальні значення кількісних параметрів системи визначаються якісними параметрами ТС вугільної шахти. Пропонована структура формування параметрів технологічної системи шахти і її підсистем дозволяє розглянути їх взаємний вплив і встановлювати оптимальні межі варіювання в залежності від зміни гірничо-геологічних умов, ведення гірських робіт [2].

При організації ефективного управління, 3 урахуванням виконання планових показників $D_{\text {план }}$, доцільно розглядати в якості глобального критерію стабілізацію сукупного видобутку вугілля $D_{u}$ на заданому рівні при змінюються рівнях видобутку окремими забоями $D_{i}$, мінімальних питомих витратах $C_{u}$ на одиницю видобутку і транспортування вантажу і роздільної транспортуванні вугілля та породи.

$$
\begin{gathered}
C_{\text {ш }}=\frac{\sum C_{i} D_{i}}{D_{u}} \rightarrow \min \\
D_{u}=\sum D_{i} \rightarrow D_{\text {план }}
\end{gathered}
$$

Для моделі очисних i підготовчих робіт, при прив'язці схемою розкриття пласта, підготовці і відпрацювання виїмкового поля обгрунтована просторово-часова послідовність робіт ТС вугільної шахти. Це модель $є$ 
International scientific and technical conference

Information Technologies in Metallurgy and Machine building - ITMM 2020

основою для об'єднання технологічних моделей, якісних характеристик вугілля, що добувається, монтажно -демонтажних робіт і внутрішньо шахтного транспорту [3].

Висновки. Запропонована система формування ММ СОДУ розрахунку виконання планових показників по шахті, 3 введенням ряду обмежень по продуктивності окремих ділянок шахти, якісних параметрів вугілля, що добувається, пропускної спроможності транспортної мережі і підйому по стовбурах дозволить оптимізувати прийняття ефективних рішень диспетчера вугільної шахти з скороченням позапланових простоїв обладнання.

\title{
Література
}

1. Слесарев В.В. Малиенко А.В. Разработка метода расчета оперативных графиков работы горнотранспортной сети // Системные технологии. Региональный межвузовский сборник научных работ.- Выпуск 5 (88). - Днепропетровск, 2013. С.110 -116.

2. Малиенко А.В «Разработка математической модели системы расчетного сопровождения добычи угля на угольных шахтах.» II -га- Міжнародна науковопрактична конференція «Сучасні наукові дослідження - 2006». Том 17. Технічні науки -Дніпропетровськ: Наука і освіта, 2006. С. -57-60.

3. Слесарев В.В. Малиенко А.В. «Управления транспортом на угольной шахте при использовании системы расчетного обоснования.» Науковий вісник НГУ № 1. Днепропетровск, 2014 р. - С.62 -66.

\section{PRINCIPLES FOR CONSTRUCTING MATHEMATICAL MODELS OF A COAL MINE SCHEDULING SYSTEM}

\author{
Malienko Andrey
}

Annotation. Successful operation of a mining company in a market economy requires maintaining a leading position in the market. Therefore, the task of optimal mining is a powerful tool for the development of the enterprise in the face of unpredictable changes in the environment. The main purpose of the study is to consider the main approaches and methods for improving the mathematical models of decision support systems by the coal mine manager.

Keywords: MATHEMATICAL MODEL, SYSTEMS OF OPERATIVE-DISPATCH MANAGEMENT, DECISION-MAKING, EFFECTIVE MANAGEMENT. 


\section{References}

1. Slesarev V.V. Malienko A.V. Development of a method for calculating operational schedules of a mining transportation network // System Technologies. Regional Interuniversity Collection of Scientific Works. - № 5 (88). - Dnepropetrovsk, 2013 .-P.110 - 116.

2. Malienko A.V. "Development of a mathematical model of a system for design support of coal mining in coal mines." II- The International Scientific-Practical Conference "Advanced Scientific Research - 2006". Volume 17. Technical sciences - Dnepropetrovsk: Science and science, 2006. P. -57-60.

3. Slesarev VV Malienko A.V. “Transport management in a coal mine using a calculation justification system.” Science Newsletter of NSU No. 1. - Dnepropetrovsk, 2014 p. P. $62-66$. 